Journal of the British Association for Chinese Studies, Vol. 8 (2), July 2018

ISSN 2048-0601

(C) British Association for Chinese Studies

\title{
Analysing Indonesian Media and Government Representation of China
}

\section{Senia Febrica}

University of Indonesia

Suzie Sudarman

University of Indonesia

\begin{abstract}
The discussion of regional leadership in Southeast Asia tends to be dominated by analysis of the relationship between the United States and China. Looking beyond great power competition this article examines how China's relations with Indonesia and Southeast Asia are represented in Indonesian national media, government documents and statements through a content analysis of government documents and media reports from 2008-2015. This is worth studying because Indonesia is the largest country in Southeast Asia and has its own aspirations of regional leadership. Using semi-structured interviews and content analysis of government documents and newspaper articles, this article presents empirical evidence that is currently lacking in research regarding perception or representation of China. The current literature on Sino-Indonesian relations points to Indonesia's ambiguity in dealing with China. The findings presented in this article support this line of argument.
\end{abstract}

Keywords: Indonesia, South China Sea, Belt Road Initiative, Southeast Asia.

Academics and practitioners pay close attention to the economic and political dynamics of Southeast Asia due to the region's economic potential and the implications of territorial conflict in the South China Sea between China and a number of the Association of the Southeast Asian Nations (ASEAN) member states. The discussion of China's regional leadership in Southeast Asia has been dominated by interpretation regarding interaction and competition

This research benefited from funding provided by the Universitas Indonesia Sinergisme Grant 2015, and the Sumitomo Foundation Grant 2016. 
between two great powers, the United States (US) and China in the region. This article aims to contribute to the literature on China's role in Southeast Asia by looking beyond great power competition in the region. It seeks to understand how China and China's leadership is presented in media and government discourse in Indonesia, the largest country in Southeast Asia that has the potential to be a regional leader, through the combination of semistructured interviews and content analysis, a technique which is broadly unexplored in the literature on Sino-Indonesian relations. By doing so, it presents empirical evidence that contributes to the argument presented in the literature regarding Indonesia's ambivalent representation of China.

Both economic and security dynamics in Southeast Asia raise a question pertaining to the possibility of China's involvement in the region. Collectively, Southeast Asian countries are the 11th largest economy and fourth largest exporter for manufactured products, services and technology (Oxford Project Southeast Asia, 2015) in the world. The region's vast land area covers 4.4 million kilometres and is located at the centre of the world economic corridors: between Europe and East Asia, Australia and East Asia and the Persian Gulf and Japan (Coutrier, 1988: 186-188; Invest ASEAN, 2015). China actively promotes economic and maritime cooperation in Southeast Asia through various initiatives including the Belt Road Initiative (BRI) and the Asian Infrastructure Investment Bank (AIIB). However, despite the positive cooperation and progress between China and Southeast Asian countries, the political dynamics within the region are not trouble-free.

Southeast Asia is known as the "arc of crisis" where maritime disputes and border conflicts take place (Calder, 2004: 135-157). The growing disputes in the South China Sea have raised concerns regarding the potential escalation of conflict. In a number of incidents, China's increasing coordination and physical support between its maritime agencies and fishermen in the South China Sea has led to friction with Southeast Asian countries, including Indonesian maritime authorities (Pitlo, 2013). From 2007 to 2015, the Indonesian maritime agencies arrested 31 China-flagged vessels (Kementerian Kelautan dan Perikanan, 2015). In 2010, a Chinese naval vessel confronted an Indonesian patrol boat and demanded the release of a Chinese trawler that had fished illegally in Natuna waters. This incident was widely reported by the 
media. An Indonesian official claimed that at least three such incidents between Indonesia's maritime authorities and its Chinese counterparts took place in 2010 alone, with one of them involving the shooting of an Indonesian citizen. ${ }^{1}$ In 2013, armed Chinese vessels compelled an Indonesian maritime and fisheries ministry patrol boat to release Chinese fishermen apprehended in Natuna waters (Reuters, 2014).

This article will provide a detailed analysis of Indonesian media and government representation of Indonesia-China bilateral relations and China's leadership in Southeast Asia. Understanding Indonesia's portrayal over the involvement of China in Southeast Asia is important since Indonesia has long been seen as the "natural born leader or first among equals within the ASEAN" (Roberts \& Widyaningsih, 2015: 264). The views expressed in its media will therefore provide us with a better understanding of how China is presented in Indonesia's public discourse, the ASEAN's largest country, which has its own aspiration for regional leadership.

This article will present the findings generated from the analysis of Indonesian media, government documents and interviews with officials. Given the history of troubled relations between the two governments, one might expect China to be presented negatively by the Indonesian media and government. According to Drake most Indonesians believe that the government of China provided financial and political support to an attempted coup on September 30, 1965 conducted by junior leftist Indonesian army officers and the Indonesian Communist Party (Drake, 1991: 216). Despite little to no evidence of China's involvement in the attempted coup, this incident led to Indonesia's complete break in diplomatic relations with China from 1967 until 1990 (Williams, 1991: 149).

On the other hand, there are also reasons why China may be cast in a positive light. Since the restoration of diplomatic ties in 1990, Sino-Indonesian relations have improved significantly. On April 25, 2005 Indonesia and China signed the Strategic Partnership arrangement which includes cooperation to address transnational crimes, improve maritime capacity building, and

\footnotetext{
${ }^{1}$ Interview with an Indonesian official (Jakarta, April 7, 2015).
} 
strengthen the development of infrastructure such as roads, bridges, and ports (Indonesian MoD, 2008: 148). As an attempt to provide a legal umbrella to govern their defence cooperation in November 2007, the two countries signed an Agreement on Cooperation Activities in the Field of Defence (Indonesian MFA, 2012). Indonesia concluded its defence cooperation with China ahead of the US-Indonesia Defence Framework Arrangement that was only signed in June 2010.

The following section provides a broader context by reviewing the existing literature on China's regional leadership. This article then proceeds with an explanation of the research methodology that we used. In order to understand how China is viewed by the Indonesian government and media we combined elite interviews and content analysis of interview transcripts, government documents, and newspaper articles. We carried out ten interviews, and analysed over 60 government documents, and more than two hundred newspaper articles. The empirical findings presented in this article support the current understanding of Sino-Indonesian relations. The findings highlight Indonesia's ambivalent behaviour towards China.

\section{Framing China's Regional Leadership}

The literature on Sino-Indonesia relations touches upon four key themes including economic relations, the transition from troubled relations to normalisation, current Sino-Indonesian relations, and China's leadership in Southeast Asia.

Scholarly works that touch upon the theme of Sino-Indonesian economic relations explain the development of economic cooperation between the two countries from the 1980 s to the present, identify the cooperation benefits, and offer recommendations to improve cooperation in this area $(\mathrm{Wu}, 2011$ : 119-141; Atje \& Gaduh, 1999:1-24; Williams, 1991: 145-158). Williams explains the interplay between economic and political interests that led to SinoIndonesian normalisation of diplomatic relations in August 1990. He points out that the Indonesian Chamber of Commerce and Industry had been vocal in

its demand for the restoration of diplomatic relations, which helped to achieve 
the breakthrough in restoring Indonesian and Chinese relations (Williams, 1991: 151, 154, 156). For Indonesian businesses, the resumption of direct trading between Indonesia and China meant that they would not need to pay a substantial cut of their profits to traders in third countries such as Singapore and Hong Kong (Williams, 1991: 154). Atje and Gaduh argue that China's increased integration into the world market brings benefits to Indonesia's and Asian economies as a whole. According to them, China's participation in the World Trade Organization and the ASEAN+3 provides room for Jakarta to build an economic relationship with Beijing that is more detached from politics. Atje and Gaduh further explain that China's involvement in the ASEAN+3 promotes cooperation in financial, monetary and other economic fields, and serves to encourage integration of Asian economies (Atje \& Gaduh, 1999: 20). Wu claims that since China has become Indonesia's 4th biggest trading partner, the two countries have become closer in various fields. These range from tourism to population/family planning programmes (Wu, 2011: 119).

Scholars such as Suryadinata and Drake focus on the transition from a troubled past to the renewal of political ties between the two countries in 1990. They trace the reasons underpinning the long political break between Jakarta and Beijing, and the renewal of diplomatic relations (see Suryadinata, 1990: 682-696; Drake, 1991: 214-221). These works map the historical events that led Indonesia to freeze its diplomatic relations with China, issues that hinder restoration of formal ties for over twenty years, and contributing factors to normalisation. Suryadinata argues that Indonesian President Suharto's desire to play a major role in world politics was a key contributing factor in shaping the decision on normalisation (Suryadinata, 1990: 690). Although some Indonesian leaders, such as the Chairman of the Parliament's Foreign Relations Committee, H. Imron Rosyadi, and the Governor of the Institute of National Defence, General Subiyakto, opposed the idea of normalisation, they could not do much because Suharto had the final say (Suryadinata, 1990: 693, 696). Drake points out that the renewal of diplomatic ties between Indonesia and China was informed by China's efforts to develop a new image as a responsible international power, Indonesia's willingness to maintain regional stability, the two countries' agreement not to tamper with the sensitive issue of the role and status of ethnic Chinese in Indonesia, the need to expand bilateral trade, and the decline of superpowers' dominant role 
in the East Asian region, which enables Indonesia and China to pay more attention to each other (Drake, 1991: 214).

A third line of research found in the literature on Sino-Indonesian relations highlights the dynamics of Indonesia's response towards the rise of China. Hong argues that the current new wave of China fever has a precedent in modern Indonesian history, particularly the domestic cultural scene during Soekarno's era (Hong, 2006: 204). Similar to Hong, authors such as Laksmana, Sukma, Nabbs-Keller, and Syamsul acknowledge the increasingly closer relations between Indonesia and China in recent years. Laksmana, Sukma, Nabbs-Keller and Syamsul argue that despite the growing Sino-Indonesian economic and military ties in recent years, Indonesia's policy has continued to be characterised by persistent ambivalence (Laksmana, 2011; Sukma, 2012; Nabbs-Keller, 2011; Syamsul, 2012). Despite their growing convergence of interests, Indonesia's policy behaviour towards the rise of China is marked by a combination between maintaining close relations with the US, and working closely with China through ASEAN (Syamsul, 2012: 151-153; Nabbs-Keller, 2011: 39; Sukma, 2012: 42-44; Laksmana, 2011: 26, 30-31).

Some of these works implicitly make reference to the role of representation in informing Indonesia's policy behaviour towards China. Hong points out that positive representation of China had informed the close relations between Jakarta and Beijing during Soekarno's era. This positive perception of China was influenced by both internal and external factors. Internally, a positive and dynamic image of China resulted from Indonesian intellectuals' desire to look for a non-Western model of social transformation (Hong, 2006: 182). Externally, China's cultural diplomacy portrayed China as a successful state becoming an important source of literary production and cultural consumption in Indonesia (Hong, 2006: 182). In contrast to Hong's positive historical account of Indonesia's view of China, Laksmana argues that at present among the Indonesian elite, China was viewed as "arrogant, gigantic and expansionist" (2011: 25). He further argues that among the wider public, perception of China is shaped by views of the Chinese as a separate race with different religions and a privileged economic position who are "unwilling to change and only concerned with its own well-being" (Laksmana, 2011: 25). Nabbs-Keller points out that the growing economic and foreign policy 
convergence between Indonesia and China is boosted by the effect of democratisation in Indonesia. She argues that democratisation in Indonesia has led to the "dismantling of discriminatory measures against Indonesia's ethnic Chinese" that in turn led to closer relations with China and improved relations with Indonesia's ethnic Chinese community (Nabbs-Keller, 2011: 2829). Discussion on how China's relations with Indonesia and Southeast Asia are represented in Indonesian national media and government documents and statements, however, is not central to Hong's, Laksmana's and Nabbs-Keller's works.

Studies which discuss China's leadership in Southeast Asia have been dominated by interpretations which focus on interactions, cooperation and competition between the US and China; and Southeast Asian countries' strategies to deal with superpowers' engagement in the region. Research that investigates the great powers' leadership in Southeast Asia or the Asia-Pacific focuses on the tensions and conflict between the US and China. A number of works focus on strategies employed by Southeast Asian countries to deal with the Sino-US rivalry in the region (Roy, 2005: 305-322; Ba, 2003: 622-647). Ba argues that in a context of declining US benevolence and increasing Chinese influence, ASEAN countries have chosen to expand bilateral and multilateral linkages with China (Ba, 2003: 646). According to Ba, ASEAN will continue to encourage multilateralism to mitigate China's rising influence, and ensure their own role in Southeast Asia (Ba, 2003: 646). In comparison, Roy claims that Southeast Asian countries employ two strategies in dealing with China: engaging and hedging. He argues that as part of the engagement strategy, Southeast Asian countries have made China an ASEAN dialogue partner, and formed additional organisations such as the ASEAN Regional Forum, ASEAN+3 (China, Japan and South Korea), and the Chiang Mai Initiative to integrate China into regional cooperation mechanisms (Roy, 2005: 310). Roy highlights that the hedging strategy employed by Southeast Asian countries includes maintaining defence cooperation with the US (Roy, 2005: 305). Other works look at how China's engagement with Southeast Asian countries has reshaped the regional order (Shambaugh, 2005: 64-99; 2016). Shambaugh argues that China's participation in regional organisations, and its efforts in establishing strategic partnerships, deepening bilateral relations, expanding regional economic ties, and reducing distrust in the security sphere are key 
developments in Asia (Shambaugh, 2005: 64, 72). He claims that all Asian countries and the US must adjust to the rise of China (Shambaugh, 2005: 99). According to Shambaugh, the tendency of Asian countries to bandwagon with China "is likely to become more manifest over time," although some states may hedge against Beijing's dominance (Shambaugh, 2005: 99). In his book China's Future, Shambaugh points out that as a consequence of China's sheer size, rising nationalism, strong military power, huge economy and territorial disputes, it is experiencing growing difficulties and tensions with its neighbouring countries including those in Southeast Asia (Shambaugh, 2016: 138-139). He states that "these rising tensions can be expected and even intensify in the years ahead" (Shambaugh, 2016: 138).

Overall, the existing works offer some insights on Indonesia's portrayal of China. Their works, however, do not provide a systematic analysis of Indonesian media and government views of Sino-Indonesian relations and China's leadership in the region. They are, nonetheless, a valuable resource for this article because they provide a detailed account of the history of cooperation and conflict between Indonesia and China, various cooperation arrangements between China and Southeast Asian countries, how they were established and what Indonesia could receive in exchange for participating in these arrangements. We, therefore, use the literature on Indonesia-China relations and China-Southeast Asia relations as a point of departure. Through media analysis, a study of government documents, and interview results this article enhances our understanding of how China is presented in Jakarta's strategies in dealing with Beijing.

\section{Methodology}

This article uses two qualitative methods: semi-structured interviews, and content analysis of government documents and newspaper articles. A semistructured interview method was used during field work in Indonesia. This is important for gaining new perspectives and insights into the internal politics of Indonesia. Analysis of interview results was then compared with government documents in order to look at whether there were discrepancies between the representation of China reflected in statements made by government officials, 
and government documents. For this purpose, interview subjects primarily included government officials. To trace suitable interview subjects, a snowball sampling procedure was used to select further interviewees. We carried out ten interviews in August 2015 with high government officials from the Indonesian Maritime Security Board (Badan Keamanan Laut); the Indonesian Ministry of Foreign Affairs; the Indonesian Ministry of Defence; the Indonesian Coordinating Ministry for Political, Legal and Security Affairs; the Indonesian Coordinating Ministry for Economic Affairs; and the Indonesian Ministry of Transportation. During interviews we asked a number of questions including the interviewees' view regarding China's recent initiatives such as the BRI and the establishment of the AllB; the threat and/or opportunity presented by these initiatives to Indonesia and Southeast Asia as a region; and the compatibility of the BRI with Indonesia's Maritime Axis initiative.

In order to examine how China is depicted in media and government documents, we combined interviews with content analysis of government documents and newspaper articles, a method that remains under-used in Sino-Indonesian relations studies. We used government documents and media reports in Indonesian and English. Content analysis provided us with a systematic approach to analyse, organise and retrieve evidence over large aggregates of texts (Berg, 2001: 225; Deacon et al., 2007: 119 ). It revealed the trends, patterns, and absences in how Indonesian officials, government documents and media portray China for nearly a decade (Deacon et.al, 2007: 119). We examined 64 primary documents published by Indonesian government ministries and the House of Representatives from 2003 to 2014, which touch upon Indonesia's and Southeast Asia's relations with China.

As part of the media analysis, we examined the two newspapers with the highest readership in the country. The two newspapers selected for this research are Kompas and the Jakarta Post. Leading national newspapers in Indonesia, including Kompas and the Jakarta Post, are owned by non-state corporations. We analysed 229 newspaper articles on China's relations with Indonesia and Southeast Asia published by Kompas and the Jakarta Post from January 1, 2008 to August 31, 2015. Kompas is an Indonesian language newspaper with the largest circulation in the country with around 530,000610,000 copies daily. It has been published daily by a non-state corporation 
called the Kompas Gramedia Group since June 28, 1965 (Kompas, 2017). The Jakarta Post was first published on April 25, 1983. It is the English newspaper with the biggest readership in Indonesia, with 40,000 copies daily. The Jakarta Post is owned by a non-state corporation, namely the PT Bina Media Nusantara (Merdeka, 2017).

Both Kompas and the Jakarta Post have a track record of being critical and independent newspapers in Indonesia. In 1978 Kompas received a strong warning from the Soeharto government and nearly lost its licence for writing about the president and his family (Simarmata, 2014: 64). In 2010 Kompas's editor in chief was summoned by the Indonesian police for publishing transcripts of taped records played at the Indonesian Constitutional Court (Mahkamah Konstitusi) regarding attempts to bribe members of the Indonesian Corruption Eradication Commission (Komisi Pemberantasan Korupsi) (Simarmata, 2014: 64). The Jakarta Post praised itself for being "always bold, always independent" (Jakarta Post, 2017c). The newspaper has no history of political or legal dispute with the Indonesian government. However, since its establishment the Jakarta Post has published a number of headlines that are critical of government policy, including the security forces' clash with demonstrators in East Timor during the Soeharto regime, and more recently, the government's plan to increase fuel prices (Hill, 2011: 181; Jakarta Post, 2017a; 2017b). There is no indication that the government issued certain directives to newspapers on how to cover Sino-Indonesian relations.

In order to ensure a systematic analysis, we used software named AntConc for the content analysis of media reports and government documents. AntConc is used to assist the storing, coding, and analysis of texts. Despite the strength of content analysis and the use of AntConc to analyse a large aggregate of texts, there are limitations to this method. As Hansen, Cottle, Negrine and Newbold claim, "as a method content analysis provides no pointers to what aspect of texts should be examined, or how those dimensions should be interpreted" (1998: 99). Therefore, we have to decide which aspects of the texts need to be examined, and interpret them. In order to provide working guidelines to study how China is represented in Indonesian government documents and media, we used several categories for coding content, for example: (1) acknowledgment of China's leadership in the region 
by Indonesia (presence, absence); (2) Indonesia's portrayal of China (opportunity/opportunities; benefit(s)/beneficial; threat); and (3) the claim that Indonesia makes regarding their own leadership role in Southeast Asia (leader, not a leader). We then analysed and interpreted the association of coding content with negative or positive representations of China.

\section{The Importance of Indonesia for China in Southeast Asia}

Indonesia is an important state for China due to its strategic maritime position, vast energy resources, and recognised status as the first among equals in ASEAN. It is the largest archipelago state in the world, comprising 17,480 islands and a maritime territory measuring close to 6 million square kilometres. Indonesia is located between the two key shipping routes of the Pacific and Indian Ocean, and between two continents, Asia and Australia (Indonesian Department of Defence, 2008: 145). Indonesia's waterways are central for China's trading activities, energy security and naval manoeuvres. Almost half of the world's trading goods and oil supply pass through key Indonesian straits including the Straits of Malacca and Singapore, the Strait of Sunda and the Strait of Lombok (Carana, 2004: 14; US Department of Homeland Security, 2005). The total value of goods transported via these waters is as much as US\$ 1.3 trillion annually (Bakorkamla, 2009: 34). Around 80 per cent of China's imported oil originating from the Persian Gulf transits through the Straits of Malacca and Singapore (U.S. Energy Information Administration, 2012; US Department of Defence (DoD), 2006: 33; US DoD, 2005: 33; US DoD, 2007: 8). Access to the Straits of Malacca and Singapore, the Strait of Sunda and the Strait of Lombok is also crucial for China to be able to strategically move its naval assets between the Pacific and Indian Oceans (Nabbs-Keller, 2011: 34). The importance of these sea lanes has led China to establish an MoU on Maritime Cooperation with Indonesia that incorporates various maritime security arrangements including coordinated patrol, search and rescue operations, naval visits and exercises.

Indonesia's abundant energy resources offer a secure and stable source of basic energy needs for China (Wu, 2011: 129). China's large population and rapidly growing economy have fuelled its quest for energy resources outside 
the country. China has become the largest global energy consumer, the world's largest net importer of petroleum and other liquids, and top coal producer, consumer, and importer (Energy Information Agency, 2015). Indonesia is the largest coal exporter in the world, with 8.26 billion tons of coal reserves and 104 trillion cubic feet of gas (Indonesian Ministry of Energy and Mineral, 2012; Detik, 2017). Thus, Indonesia offers great potential to supply China's fast-growing energy needs. China's growing investment in Indonesia's mining sector reflects this. China's investment in Indonesia's mining sector in $2016(47,969,400$ USD) is close to 60 times higher compared to its investment in 2007 (800,000 USD).

Indonesia also matters for China as it enjoys the status of the largest country in the region, and is a recognised leader within ASEAN. Indonesia is one of the founding members of ASEAN and has played a central role in shaping the regional architecture (Sukma, 2012: 44). Indonesia has proposed the concept of the ASEAN Security Community, actively sought to conduct conflict mediation efforts in the Vietnam-Cambodia conflict and the South China Sea disputes, developed regional mechanisms to promote democracy and human rights, and initiated the development of the ASEAN Maritime Forum (Tomotaka, 2008: 23; Emmers, 2014: 543; Febrica, 2017). There have been concerted efforts carried out by Indonesia and other ASEAN member states to draw China into regional processes ( $\mathrm{Ba}, 2003$ : 629). Each of the ASEAN multilateral dialogues, such as the South China Sea Workshops, the ASEAN+3 and the Expanded ASEAN Maritime Forum to mention a few, includes China (Ba, 2003: 629). These arrangements provide opportunities to China to offer transparency and redefine its relations with ASEAN (Ba, 2003: 629).

In conclusion, Indonesia is important, because the routes of global trade and oil, its secure base for energy resources, and its being a recognised leader in ASEAN have positioned Indonesia as a crucial player in the region. The role that Indonesia plays in China-Indonesia and China-Southeast Asia relations, therefore, can be seen as a key to the success of China's engagement in Southeast Asia and a significant achievement for regional stability and prosperity. 


\section{Findings: How China is Presented by the Indonesian Media and Government}

Indonesia sees itself as one of key powers in Southeast Asia (Kementerian Luar Negeri Indonesia, 2013: 29). ${ }^{2}$ As a leading country in the region, Indonesia feels the need to play an active role to improve the US-China interactions with Southeast Asian countries.

Our analysis of news articles, government documents and interviews with officials shows an ambiguous representation of China by the Indonesian media and government. The majority of interview results, media reports, and government and parliament documents portray Indonesia-China relations in a positive light. However, government documents, media reports and interview results also frequently depict China both as opportunity and challenge, and on a number of occasions as a threat. Interviewed officials in Indonesia articulated words such as "challenge" or "threat" together with "opportunity" when asked about their view of China. ${ }^{3}$ According to them, relations with China offer economic opportunities for Indonesia, particularly in trade and infrastructure development such as sea ports, road and train construction.

Indonesian government officials relate China's BRI with the Jokowi administration's Maritime Axis Initiative, and look for synergy between the two. ${ }^{4}$ President Jokowi announced the concept of Indonesia as the World

\footnotetext{
${ }^{2}$ Interviews with a senior official at the Indonesian Ministry of Defence (Jakarta, August 24 2015); and two officials at the Indonesian Ministry of Foreign Affairs (Jakarta, August 21 2015) ${ }^{3}$ Interviews with two senior officials at the Indonesian Maritime Security Board (Jakarta, August 26 2015); an official from the Indonesian Directorate General of Sea Transportation (Jakarta, August 7 2015) and an official from the Indonesian Directorate General of Sea Transportation (Jakarta, August 6 2015).

${ }^{4}$ Interviews with two senior officials at the Indonesian Maritime Security Board (Jakarta, August 26 2015); two senior officials from the Indonesian Ministry of Foreign Affairs (Jakarta, August 21 2015); a senior official from the Indonesian Coordinating Ministry for Political, Legal and Security Affairs (Jakarta, August 21 2015); an expert staff at the Indonesian Coordinating Ministry for Political, Legal and Security Affairs (Jakarta, August 21 2015); a senior official at
} 
Maritime Axis in his speech during the 9th East Asia Summit in Myanmar in 2014. Indonesia's Maritime Axis concept is built upon five pillars including the re-development of Indonesia's maritime culture; conservation of marine resources; the development of maritime infrastructure and connectivity by building up deep-seaports, ship industry and maritime tourism, for example; the implementation of maritime diplomacy to resolve various sources of interstate tensions including boundary disputes, illegal fishing, and marine pollution; and the development of maritime defence power (Indonesian Presidential Office, 2015).

The BRI is one of Beijing's most ambitious initiatives and has precipitated debate on China's growing leadership in Southeast Asia. The initiative was first coined by President Xi Jinping during his visit to Jakarta on October 3, 2013 (Bu, August 5 2015). The purpose of the BRI is to build efficient routes between the major sea-ports of various countries in the world from China's east coast to Europe through the South China Sea and the Indian Ocean, and into the South Pacific (China-Britain Business Council, 2016).

A former Indonesian Minister of Marine and Fisheries, Rokhmin Dahuri, claimed that "the BRI is China's international policy that has most profound influence towards Indonesia" (Dahuri, 2015: 9). The Governor of the Indonesian National Defence Institute (Lembaga Pertahanan Nasional), Agus Widjojo, suggested that although the BRI is "developed by China for China, however, there are opportunities that can be exploited by anyone, especially Indonesia" (Suropati, Sulaiman \& Montratama, 2014: 13). There is an expectation that China's BRI can offer beneficial support in the form of loans and investment to help finance Indonesia's Maritime Axis Initiative. According to an Indonesian official at the Indonesian Defence Institute and two defence experts, during President Xi Jinping's visit to Bandung and Jakarta from the 19th to the 24th of April in 2015, China offered to provide $90 \%$ of the financial support for infrastructure projects in Indonesia that are in line with the BRI (Suropati, Sulaiman \& Montratama, 2014:126).

the Indonesian Directorate General of Sea Transportation (Jakarta, August 6 2015); and a senior official at the Indonesian Ministry of Defence (Jakarta, August 24 2015) 
The Maritime Axis Initiative was introduced by President Jokowi on November 13, 2014, one year after President Xi announced the BRI in his speech before the Indonesian parliament in 2013. It is designed to transform Indonesia's development platform from land-based to maritime-based development. The Indonesian government has estimated that the Maritime Axis Initiative will increase economic growth by 1.2 trillion USD and create new jobs for 40 million Indonesians (Dahuri, 2015: 125). Under the Maritime Axis Initiative, Indonesia seeks to improve its maritime connectivity by building new ports, shipyards and shipping lines (Dahuri, 2015: 39). Currently, Indonesia is dependent on its neighbouring countries' ports to support its export-import activities. The majority of Indonesian export shipments are via the transshipment ports of Singapore and/or the Malaysian ports of Port Klang and Port Tanjung Pelepas (Febrica, 2017).

Despite China's BRI presenting opportunities to advance Indonesia's Maritime Axis Initiative, it also raises concerns, as the two are not designed to be in line with each other. The BRI aims to connect ports in China to the South China Sea, the Strait of Malacca, the Strait of Lombok, and the Strait of Sunda through to the northern part of the Indian Ocean, the Persian Gulf, the Red Sea and the Gulf of Aden (Suropati, Sulaiman \& Montratama, 2014: 115). In other words, it is designed to improve connectivity between China and other countries that are located in the main economic corridors and straits used for international navigation. The priority of the BRI in Southeast Asia is the area located close to the Straits of Malacca and Singapore that overlaps with the western part of Indonesia's maritime territory. Indonesia's maritime infrastructure in this area has been well established, particularly, if we compare it with port infrastructure in the eastern part of the country. In comparison to China's BRI, Indonesia's Maritime Axis aims to improve connections between the developed western part of the country with the underdeveloped eastern part so the price of goods between the two regions in Indonesia do not differ as much. The key priority for the Jokowi administration is the development of maritime infrastructure in the eastern part of Indonesia. This suggests that the focus of the BRI does not always coincide with Indonesia's maritime initiative. 
There are also other crucial economic and security concerns raised by Indonesian officials, such as the presence of Chinese economic spies in Indonesia; the influx of foreign workers from China to Indonesia due to the majority of China's big infrastructure projects in Indonesia not employing local workers; and the possible use of deep-port infrastructure in Indonesia by China's military establishment. ${ }^{5}$ Officials voiced their concerns that deep-ports built by China in Indonesia might be used by Beijing as sites to repair and refuel its naval ships in Southeast Asia. A senior official at the Indonesian Ministry of Foreign Affairs explained that this apprehension has been raised due to the precedent of China's naval activities in Sri Lanka. ${ }^{6}$ According to him China built a deep-port in Sri Lanka and later used the port facilities for its naval vessels to visit and re-supply. He pointed out that Indonesia is not willing to accept such an arrangement if China wins the bid to develop ports in Indonesia. ${ }^{7}$ To quote him:

The Maritime Silk Road is interesting. We can use the opportunities offered by [the BRI] but we also need to be prudent ... If we look at Sri Lanka, the Maldives and Bangladesh's experiences, economic factors are not the only concern here. Normally, when China is developing a port ... part of this port management will be handled by them. In the case of Sri Lanka and the Maldives, as China control the port management, their warships [can] enter [the port facility]. This is a concern that we need to pay attention to. ${ }^{8}$

During interviews, officials used the term "challenge" or "threat" together with "opportunities" when describing China's relations with Indonesia. Indonesian government officials used the word "threat" to describe Sino-

\footnotetext{
${ }^{5}$ Interviews with two senior officials at the Indonesian Maritime Security Board (Jakarta, August 26 2015; and two senior officials at the Indonesian Ministry of Foreign Affairs (Jakarta, August 21 2015).

${ }^{6}$ Interview with a senior official at the Indonesian Ministry of Foreign Affairs (Jakarta, August 21 2015).

${ }^{7}$ Interview with a senior official at the Indonesian Ministry of Foreign Affairs (Jakarta, August $212015)$.

${ }^{8}$ Interview with a senior official at the Indonesian Ministry of Foreign Affairs (Jakarta, August 21 2015).
} 
Indonesian interactions in the South China Sea. Indonesian government officials frequently asserted that due to the proximity of Natuna to the disputed area, and the absence of China's clarification on whether or not its claims encompass Indonesia's exclusive economic zone, the growing tension in the South China Sea does pose a threat to Indonesia. ${ }^{9}$ In comparison to interview results, there are no Indonesian government documents published from 2008 to 2015 that explicitly frame China as a threat to Indonesia. Government documents mention China as Indonesia's strategic partner in creating cooperation opportunities and facing common challenges. There are no documents that state China is a source of military or security threats. There is only one document that refers to China as a source of economic challenges. The document suggests that "cheap products from China that flooded the Indonesian market" could bring dire effects to the archipelago's economy (Kemenkopolhukam, 2007: 34). The majority of Indonesian government documents that make any remark about Jakarta-Beijing relations put emphasis on cooperation opportunities between the two countries in the oil industry, technology and in infrastructure development.

Documents published by the Indonesian Parliament portray China in a positive manner. The relations between Indonesia and China are seen as involving mutual cooperation that provides opportunities for the Indonesian government to improve the country's economic growth (DPR, 2014a; DPR, 2014b; DPR, 2014c; DPR, 2014d). The word "threat" is absent from all documents published by Parliament. Rather, the words that are commonly used are "opportunities" (used sixteen times); and "benefit" (used six times) to exclusively portray China in a positive light.

The articulation of economic opportunity and the benefits offered by Indonesia-China relations are featured in articles published by Indonesian newspapers.

\footnotetext{
${ }^{9}$ Interviews with two officials from the Indonesian Bakamla, August 26 2015, an official from the Indonesian Coordinating Ministry for Political, Legal and Security Affairs, August 212015 , an official from the Indonesian Ministry of Defence, August 24 2015, Jakarta.
} 
Table 1. Frequency of Keywords and Representation of China in Articles Published by Jakarta Post

\begin{tabular}{|c|c|c|c|c|c|c|}
\hline \multirow{2}{*}{ Year } & \multicolumn{2}{|c|}{ Opportunity/opportunities } & \multicolumn{2}{c|}{ Benefit/beneficial } & \multicolumn{2}{c|}{ Threat } \\
\cline { 2 - 7 } & Positive & Negative & Positive & Negative & Positive & Negative \\
\hline 2008 & 2 & 0 & 2 & 0 & 0 & 0 \\
\hline 2009 & 2 & 0 & 8 & 1 & 1 & 1 \\
\hline 2010 & 0 & 0 & 8 & 0 & 0 & 0 \\
\hline 2011 & 2 & 0 & 1 & 0 & 0 & 1 \\
\hline 2012 & 0 & 0 & 0 & 0 & 0 & 0 \\
\hline 2013 & 1 & 0 & 0 & 1 & 0 & 2 \\
\hline 2014 & 2 & 1 & 3 & 4 & 0 & 9 \\
\hline 2015 & 5 & 0 & 5 & 7 & 0 & 6 \\
\hline Total & 14 & 1 & $\mathbf{2 7}$ & $\mathbf{1 3}$ & 1 & 19 \\
\hline
\end{tabular}

In Indonesian newspapers, however, keywords such as "opportunity" or "opportunities, and "benefits" or "beneficial" are mostly but not exclusively used to show positive representation of China. As Table 1 shows the words "opportunity/opportunities" (was used 14 times), and "benefit/beneficial" (was used 27 times) in articles published by the Jakarta Post from 2008 to 2015 to describe the positive aspect of China's and Indonesia's bilateral relations. China is seen by Indonesia as the largest trading partner, a supplier of weaponry, and a source of investment to develop infrastructure the country badly needs, including sea ports and railway networks (Supriyanto, 2014; Witular, 2014; Jakarta Post, 2009).

Negative association with the words "opportunity/opportunities" appeared only once in 2014 in a Jakarta Post article explaining the Komodo Naval Exercise in Natuna waters as a measure for Indonesia to assert its role in South China Sea. This article was written against the backdrop of a series of political events including the launch of the multilateral Komodo Naval exercise hosted by Indonesia in 2014, a series of conflicts between Indonesian and Chinese maritime authorities over Chinese fishermen's illegal fishing activities in Natuna waters; and China's naval exercise in the Indian Ocean in 2014 that 
involved transiting through the Indonesian Straits of Sunda and Lombok. The word "benefit" or "beneficial" when pointing to a negative representation of China was mainly used from 2013 to 2015 to critically question the benefits of China's aggressive actions in the South China Sea in informing Beijing's relations with Indonesia and ASEAN. Major political events that derived this negative association include China's military build-up in the region from 2013 to 2015, Chinese official statements defending the construction of artificial islands in the South China Sea in May 2015, and the 26th ASEAN Summit in Kuala Lumpur, where Southeast Asian leaders discussed various regional issues including the South China Sea.

Table 2 below shows that the words "opportunity/opportunities" appeared 28 times and "benefit/beneficial" appeared 36 times in Kompas articles published from 2008 to 2015, and were used to provide a positive portrayal of China. This suggests that the words opportunity/opportunities and benefit/beneficial are mainly associated with a positive representation of China by Kompas. Major political events surrounding the positive representation of China in the Jakarta Post and Kompas mainly include official visits by the Chinese president, political leaders and business representatives to Indonesia, and vice-versa, and the signing of economic or defence deals between the two countries. From 2010 to 2015 the words "opportunity/opportunities" and "benefit/beneficial" were also used to depict China in a negative light. In 2010 these words were used to explain the negative implications of the ASEAN-China Free Trade Area (ACFTA) to Indonesia. There were concerns that the implementation of ACFTA in 2010 would provide greater opportunities for China to supply more products to the Indonesian market. The weakening of the Chinese yuan was the reason underpinning the negative portrayal of China in 2011. From 2012 to 2015 a number of major political events informed the publication of articles that displayed negative associations between China's regional leadership and the words "opportunity/opportunities" and "benefit/beneficial." These include disagreements between the Cambodian Prime Minister Hun Sen and the Philippine President Benigno Aquino III regarding ASEAN's consensus not to internationalise South China Sea disputes during the ASEAN Summit in Phnom Penh in 2012; the firing of warning shots to Vietnamese and Filipino fishermen by China's maritime authorities; the deployment of Chinese warships to 
prevent the Philippine ships exploring oil in the area in the same year; and the deepening of the trade deficit between Indonesia and China following the implementation of ACFTA in 2010.

Table 2. Frequency of Keywords and Representation of China in Articles Published by Kompas

\begin{tabular}{|c|c|c|c|c|c|c|}
\hline \multirow{2}{*}{ Year } & \multicolumn{2}{|c|}{ Opportunity/opportunities } & \multicolumn{2}{c|}{ Benefit/beneficial } & \multicolumn{2}{c|}{ Threat } \\
\cline { 2 - 7 } & Positive & Negative & Positive & Negative & Positive & Negative \\
\hline 2008 & 0 & 0 & 0 & 0 & 0 & 0 \\
\hline 2009 & 4 & 0 & 0 & 0 & 2 & 0 \\
\hline 2010 & 1 & 6 & 5 & 1 & 0 & 2 \\
\hline 2011 & 3 & 1 & 5 & 0 & 0 & 4 \\
\hline 2012 & 2 & 1 & 6 & 0 & 2 & 0 \\
\hline 2013 & 2 & 4 & 2 & 0 & 0 & 3 \\
\hline 2014 & 9 & 0 & 14 & 0 & 1 & 2 \\
\hline 2015 & 7 & 2 & 4 & 2 & 0 & 5 \\
\hline Total & $\mathbf{2 8}$ & $\mathbf{1 4}$ & $\mathbf{3 6}$ & $\mathbf{3}$ & $\mathbf{5}$ & $\mathbf{1 6}$ \\
\hline
\end{tabular}

In comparison to the positive representation of China highlighted in documents published by the Indonesian government and Parliament, articles published by Indonesian national newspapers openly referred to China as a threat to Indonesia. The word "threat" is mainly associated with a negative representation of China. The word "threat" - when related to a positive representation of China in the Indonesian media-only appeared once in the Jakarta Post and five times in Kompas. Here, the word threat mainly refers to common threats faced by Indonesia, China, and the East Asian community such as terrorism and other transnational crimes. As shown in Table 2, articles published by Kompas from 2008 to 2015 show that the word "threat" was used 16 times to describe China in a negative manner. The word was used in articles published by Kompas mainly due to China's growing aggressiveness in the South China Sea disputes, the growing scale of imported products from China that entered the Indonesian market after ACFTA came into effect, and illegal fishing activities by Chinese fishermen in Indonesian waters.

As shown in Table 1, China has not always been depicted as a beneficial partner in the Jakarta Post. Threats posed by China range from lower-level 
political issues such as the growing number of Chinese goods entering the Indonesian market after ACFTA came into force on $1^{\text {st }}$ January 2010, to higherlevel political issues such as the South China Sea territorial disputes. The newspaper used the word "threat" 19 times to specifically discuss negative representations of China.

China's engagement in the South China Sea has been the main topic in the Jakarta Post when discussing the threat of China to the peace and stability of Southeast Asia. The words "South China Sea" (Laut China Selatan/Laut Cina Selatan) were used 343 times in the Jakarta Post and 54 times in Kompas articles. The word "threat" was mainly used when explaining China's involvement in the South China Sea disputes.

Table 3. Frequency of the Word "Threat" in Indonesian Newspapers and Negative Representation of China in the South China Sea Disputes

\begin{tabular}{|c|c|c|l|}
\hline Year & $\begin{array}{c}\text { Jakarta } \\
\text { Post }\end{array}$ & Kompas & \multicolumn{1}{c|}{ Corresponding Major Political Event(s) } \\
\hline 2008 & 0 & 0 & \\
\hline 2009 & 0 & 0 & \\
\hline 2010 & 0 & 0 & \\
\hline 2011 & 1 & 0 & $\begin{array}{l}\text { China's military build-up in the South China Sea including the } \\
\text { placement of China's nuclear submarine, warships and a network } \\
\text { of underground tunnels at the Sanya base on the southern tip of } \\
\text { Hainan island. }\end{array}$ \\
\hline 2012 & 0 & 0 & \multicolumn{1}{|c|}{ - } \\
\hline 2013 & 2 & 2 & $\begin{array}{l}\text { The 12 } \\
\text { Summit, International Institute for Strategic Studies Asia Security }\end{array}$ \\
\hline 2014 & 9 & 2 & $\begin{array}{l}\text { China's fishing restrictions in the South China Sea, the } \\
\text { establishment of Air Defence in the East China Sea, a naval } \\
\text { blockade around Second Thomas Shoal, and inclusion of part of } \\
\text { Indonesia's Natuna Islands waters in China's territorial map. }\end{array}$ \\
\hline 2015 & 6 & 5 & $\begin{array}{l}\text { The 2015 ASEAN Summit in Kuala Lumpur; China's rapid progress } \\
\text { in building an airstrip suitable for military use in the Spratly Islands; } \\
\text { and the signing of the AllB Articles of Agreement in June 2015. }\end{array}$ \\
\hline
\end{tabular}

As shown in Table 3, from 2008 to 2010 there was no mention of China's involvement in the South China Sea disputes as a threat to Indonesia and the region either in the Jakarta Post or in Kompas. From 2013 to 2015, China's increasing military build-up; and its policy measures to restrict fishing activities 
for foreign vessels, to impose a naval blockade, to include part of Indonesia's Natuna waters in its map, and to construct artificial islands in the South China Sea have shifted the Indonesian media's representation of China. Table 3 shows that from 2013 to 2015 the Jakarta Post and Kompas increasingly articulated China as a threat in the context of the South China Sea disputes. From 2013 to 2015, the Jakarta Post identified China's behaviour in the South China Sea disputes as a threat 17 times, and Kompas 9 times.

In the context of the South China Sea disputes, Indonesia was depicted as a neutral state and a peace broker between China and other claimant states in Southeast Asia including Malaysia, the Philippines, Vietnam, and Brunei. A number of phrases were used to describe Indonesia's position in the South China Sea territorial disputes. These include "neutral stance", "a neutral broker", and "neutral position" (Jakarta Post, 2015a; Supriyanto, 2014; Arsana, 2012).

China's growing assertiveness in Southeast Asia has also served as a key discussion topic in the Indonesian media. Both Kompas and the Jakarta Post focused their news reporting on a range of issues including China's leadership in the development of the ASEAN-China Free Trade Agreement, China's role as a host of APEC and G-20 meetings in 2014, and Beijing's new initiatives including the BRI and the AllB. Of all the new initiatives introduced by China in recent years, media attention focuses on the AlIB and the BRI. From 2008 to 2015, the AllB was discussed 91 times in news articles published by Kompas, and 65 times in the Jakarta Post. The BRI (Jalan Sutra Maritim) was mentioned 18 times in articles published by Kompas, and 8 times in the Jakarta Post from 2008 to 2015.

The AllB fund is portrayed in the media as a potential source of assistance to support Indonesia's Maritime Axis ambition. The AllB is expected to fund the development of 24 seaports, 15 airports, 1,000 kilometres of road, 8,700 kilometres of railway networks, and power plants with a 35,000-megawatt capacity (Jakarta Post, 2015b). Despite the AllB promising investment in Indonesia, the media also raised concern over China's low success rate in finalising its investment projects in Indonesia. This circumstance has generated doubt over the realisation of the AIIB investment projects in Indonesia. The 
Indonesian Capital Investment Coordinating Board (Badan Koordinasi Penanaman Modal) pointed out that the success ratio of China's development projects in Indonesia is 1:10. This is very low in comparison to the success rate of Japan's development projects, which reaches 6.5:10 (Jakarta Post, May 2 2015). News articles published in 2008-2015 that discuss the negative aspects of Indonesia's and China's economic relations, such as the one that explained the low success rate of China's investment projects in Indonesia, are very few (Jakarta Post, 2015b). Despite there being a widespread perception that China and Japan are engaging in a tight investment race in Indonesia, the data from the Indonesian Investment Coordinating Board (Badan Koordinasi Penanaman Modal) also shows that in 2016 alone the value of Japan's investment in Indonesia's infrastructure sector was five time higher than that of China. Japan's investment in five infrastructure sectors including the transportation industry; electricity, gas and water; construction; transportation, warehouses and telecommunications in 2016 reached US\$2,547,294,800 (Pusat Data dan Informasi Badan Koordinasi Penanaman Modal, 2017). By comparison, China's investment in the same five infrastructure sectors only reached US\$465,729,000 (Pusat Data dan Informasi Badan Koordinasi Penanaman Modal, June 25 2017). The progress of the Indonesian Patimban Port and other maritime infrastructure projects that involve cooperation with Japan shows Tokyo's positive performance in implementing its investment projects.

The majority of Indonesian news articles tend to discuss the benefits that Indonesia can gain from the AllB, especially to support Indonesia's Maritime Axis Initiative. China's low performance in delivering its investment projects in other countries was not reported in newspaper articles published in Kompas and the Jakarta Post from January 12008 to August 31 2015. An eight-year-old Chinese-operated port, namely, Hambantota port in the southern part of Sri Lanka, for instance, is a prime example of China's weak performance in the BRI. As reported by the Straits Times this port has "almost no container traffic and trampled fences that elephants traverse with ease" (Straits Times, 2018). In Vietnam delays, disruption, cost overruns, and accidents have prompted criticism of a Chinese-built railway section of Hanoi's (Financial Times, 2016). This put the project in unfavourable contrast to other infrastructure projects that are built by Japanese and South Korean firms (Financial Times, 2016). In Hanoi, a Japanese consortium including Japan's Sumitomo is building the Ho 
Chi Minh City project, while the China Railway Engineering Cooperation has a contract to build one railway line, and a South Korean firm, Daelim, gained a contract to build another (Financial Times, 2016). Despite there being cases of China's weak performance in delivering BRI projects, as shown in the case of the Hambantota port or Hanoi's new railway, news items such as these were not widely reported in Indonesia.

\section{Conclusion}

To conclude, based on the evidence analysed here, Indonesia presents Indonesia-China relations and China's leadership in Southeast Asia with a degree of ambiguity. On the one hand, the Indonesian media and government presented China as a strategic partner that can provide economic opportunities. On the other hand, Indonesia depicted China as a "less than benign" power due to Beijing's growing military activities in the South China Sea, the negative implications of the ACFTA deal to the Indonesian economy, and concerns over potential misuse of joint port infrastructure projects for China's military activities.

Analysis of media reports, government documents, and interviews with Indonesian officials show three important points. First, our analysis of articles published by the Jakarta Post and Kompas shows that China is more often portrayed in a positive light. The use of the words "opportunity/opportunities" and "benefit/beneficial", when associated with negative representation of China, only began in 2010 when ACFTA came into force.

Second, the word "threat" is mostly used both in the Jakarta Post and Kompas to refer to China's aggressive behaviour in the South China Sea disputes. From 2008 to 2010, articles published in both newspapers did not mention China as a threat in the South China Sea. Between 2013 and 2015, we observed an increased use of the word "threat", pointing to China's negative behaviour in the South China Sea, in the Jakarta Post and Kompas. The increased portrayal of China as a threat in Indonesian newspapers has taken place against the backdrop of China's decision to implement an array of policies in the South China Sea including the deployment of warships and 
submarines, imposing fishery restrictions for foreign vessels, implementing naval blockades, incorporating parts of Indonesian Natuna waters in China's map, and constructing artificial islands during the same period. It is natural to conclude that the negative portrayal of China should increase.

Third, out of all of China's proposed initiatives in Southeast Asia, the BRI and the AIIB have received the most attention both from government officials and the media. China's BRI is often compared and discussed together with the Indonesian Maritime Axis Initiative. Although China's success rate in project implementation compares unfavourably to Japan, the AllB is seen as a source of potential funding to support infrastructure projects under the Maritime Axis Initiative. China's low success rate in project implementation in Indonesia is in line with comments about Beijing's BRI performance in other parts of the world such as Sri Lanka and Vietnam, where the projects do not appear to be as successful as China claims.

Taken as a whole, this article shows Indonesia's ambivalent representation of and commentary on China. The current literature on Sino-Indonesian relations points to Indonesia's ambiguity in dealing with China. The findings presented in this article support this picture. This article adds to the current literature by providing empirical evidence that resulted from content analysis of interview transcripts, government documents and newspaper articles, a method that is under-explored in Sino-Indonesian relations studies.

\section{Bibliography}

Arsana, I Made Andi (2012), "RI Position in the South China Sea Dispute", Jakarta Post, September 29.

Asmoro, Andry (2009), "ASEAN-China Free Trade Deal: Let's Face the Music", Jakarta Post, December 23.

Atje, Raymond and Arya B. Gaduh (1999), "Indonesia-China Economic Relations: An Indonesian Perspective", CSIS Working Paper Series WPE 052.

Ba, Alice D. (2003), "China and ASEAN: Re-navigating Relations for a 21st Century Asia", Asian Survey 43(4): 622-647. 
Badan Koordinasi Keamanan Laut (Bakorkamla) (2010), Buku Putih Bakorkamla 2009, Jakarta: Pustaka Cakra.

Berg, Bruce Lawrence (2001), Qualitative Research Methods for the Social Sciences, Boston: Allyn \& Bacon.

$\mathrm{Bu}$, Xu (2015), "Maritime Silk Road Can Bridge China-ASEAN Cooperation," Jakarta Post, August 5, available at: http://www.thejakartapost.com/news/ 2015/08/05/maritime-silk-road-can-bridge-china-asean-cooperation.html (accessed 18.01.2016).

Calder, Kent E. (2004), "Securing Security through Prosperity: The San Francisco System in Comparative Perspective", Pacific Review 17(1): 13557.

Carana (2004), Impact of Transport and Logistics on Indonesia's Trade Competitiveness, available at: http://www.carana.com/images/PDF_car/ Indonesia\%20Transport\%20and\%2

OLogistics\%20Report.pdf (accessed 20.01.2011).

Coutrier, P.L. (1988), "Living on an Oil Highway", Ambio 17(3): 186-188.

Dahuri, Rokhmin (2015), Menuju Indonesia Sebagai Poros Maritim Dunia, Bogor: Roda Bahari.

Deacon, David, Michael Pickering, Peter Golding and Graham Murdock (2007), Researching Communication: A Practical Guide to Methods in Media and Cultural Analysis (2nd ed.), New York: Oxford University Press.

Detik (2017), "RI Punya Cadangan Batubara 24 Miliar Ton yang Masih 'Perawan'”, available at: https://finance.detik.com/infografis/3417754/ripunya-cadangan-batu-bara-24-miliar-ton-

yang-masih-perawan (accessed 01.08.2017).

Dewan Perwakilan Rakyat (DPR) (2014a), “Hubungan Bilateral Indonesia-China Semakin Erat", February 10, available at: http://www.dpr.go.id/berita/det ail/id/7571 (accessed 14.08.2015).

DPR (2014b), “DPR Apresiasi Sikap Tiongkok Soal Perdagangan”, June 9, available at: http://www.dpr.go.id/berita/detail/id/8148 (accessed 14.08. 2015).

- - (2014c), "Tiongkok Ingin Tingkatkan Investasi", June 30, available at: http://www.dpr.go.id/berita/detail/id/8302 (accessed 14.08.2015). 
- (2014d), "Nilai Perdagangan Indonesia-China Harus Seimbang", September 15, available at: http://www.dpr.go.id/berita/detail/id/8716 (accessed 14.08.2015).

Drake, Earl (1991), "Indonesia and China: Old Habits and New internationalism", The Pacific Review 4(3): 214-221.

Emmers, Ralf (2014), "Indonesia's Role in ASEAN: A Case of Incomplete and Sectorial Leadership", The Pacific Review 27(4): 543-562.

Energy Information Agency (2015), "China", available at: https://www.eia.gov/beta/international/analysis.cfm?iso=CHN (accessed 01.08.2017).

Febrica, Senia (2017), Maritime Security and Indonesia: Cooperation, Interests and Strategies, London: Routledge.

Financial Times (2016), "Tale of Two Metro Lines Shows Battle for Business in Vietnam", January 22, available at: https://www.ft.com/content/dde43a4 a-c0de-11e5-a8c6-deeeb63d6d4b (accessed 08.07.2018).

Fravel, M. Taylor (2016), "Traditional Fishing Grounds and China's Historic Rights Claims in the South China Sea", July 11, available at: www.maritimeawarenessproject.org (accessed 05.10.2016).

Hadi, Syamsul (2012), "Indonesia, ASEAN and the Rise of China: Indonesia in the Midst of East Asia's Dynamics in the Post-Global Crisis," World 3(2): 151-166.

Hansen, Anders, Simon Cottle, Ralph Negrine and Chris Newbold (1998), Mass Communication Research Methods, New York: Palgrave.

Hill, David T. (2011), Pers Di Masa Orde Baru, Jakarta: Yayasan Pustaka Obor Indonesia dan Lembaga Studi Pers dan Pembangunan.

Hong, Liu (2006), "The Transnational Construction of 'National Allegory' China and the Cultural Politics of Postcolonial Indonesia", Critical Asian Studies 38(3): 179-210.

Indonesian Department of Defence (2008), Defence White Paper, Jakarta: Ministry of Defence.

Indonesian Ministry of Energy and Mineral Resources (2012), "Indonesian Oil Reserves Exploration is So High", available at http://www3.esdm.go.id/new s-archives/oil-and-gas/47-oilandgas/5557-indonesian-oil-reserves-explora tion-is-so-high.html?tmpl=component\&print=1\&page= $($ accessed 01.08 .20 17). 
Indonesian Ministry of Marine and Fishery Affairs (2015), "Rekapitulasi Kapal Hasil Tangkapan Kapal Pengawas Berdasarkan Kebangsaan Kapal”, March 19.

Indonesian Presidential Office (2015), “Indonesia Sebagai Poros Maritim Dunia", November 13, available at: http://www.presidenri.go.id/maritim/indonesi a-sebagai-poros-maritim-dunia.html (accessed 04.05.2016).

Invest ASEAN (2015), "Integrated ASEAN", February 2, available at: http://investasean.asean.org/index.php/page/view/about-theaseanregion /view/707/newsid/932/integrated-asean.html (accessed 05.04.2016).

Jakarta Post (2009), "Sino-RI Relations Hit New High", May 27.

- - (2015a), "ASEAN Bolster Strong Ties in Face of China", April 28.

- - (2015b), "RI Should Seeks Better Realization in AllB Projects", May 2.

- - (2017a), "Pertamina Says Fuel Prices Need to Be Increased", 17 November, available at: http://www.thejakartapost.com/news/.../pertamina-says-fuel-pricesneed-to-be-increased.html (accessed 19.12.2017).

- - (2017b), "Government Mulls Fuel Price Hike to Keep Up with Oil Process," December 6, available at: http://www.thejakartapost.com/news/2017/12 /06/government-mulls-fuel-price-hike-to-keep-up-with-oil-prices.html (accessed 19.12.2017).

- - (2017c), "The Jakarta Post-Always Bold. Always Independent", December 19, available at: http://www.thejakartapost.com/ (accessed 19.12.2017).

Kementerian Koordinator Bidang Politik Hukum dan Keamanan Republik Indonesia (Kemenkopolhukam) (2007), Kumpulan Pidato Menteri Koordinator Bidang Politik, Hukum dan Keamanan Republik Indonesia Laksamana (Purnawirawan) Widodo Adi Sucipto Sepanjang Tahun 20042007, Jakarta: Kemenkopolhukam.

Kementerian Luar Negeri Republik Indonesia (2013), “Profile: Dr. R. M. Marty M. Natalegawa", Buletin Komunitas ASEAN, Jakarta: Kementerian Luar Negeri Republik Indonesia, available at: https://books.google.com.tw/book $s ? i d=12 K 2 B g A A Q B A J \& p g=P A 29 \& \mid p g=P A 29 \& d q=$ indonesia,+ pemimpin+ASE AN,+kementerian\&source=bl\&ots=uGOKv6C9YJ\&sig=SkHUMPrICe7NpSKs 3qw2RHli6KI\&hl=en\&sa=X\&ved=0CEwQ6AEwB2oVChMIvMKmvuaWyAIVS 
SSUCh2cXwFs\#v=onepage\&q=indonesia\%2C\%20pemimpin\%20ASEAN\%2C \%20kementerian\& $f=$ false (accessed 27.09.2015).

Kompas, (2017), "52 Tahun Harian Kompas dan Warisan Jurnalisme Jakob Oetama", June 28, available at: http://nasional.kompas.com/read/2017/06

/28/11073611/52.tahun.harian.kompas.dan.warisan.jurnalisme.jakob.oet ama (accessed 16.08.2017)

Kurth, James (2007), "Globalization and Empire: The Effects of 9/11 and the Iraq War", 148-172, in Bruce Mazlish, Nayan Chanda and Kenneth Weisbrode (eds.), The Paradox of a Global USA, Stanford: Stanford University Press.

Laksmana, Evan A. (2011), "Variations on A Theme: Dimensions of Ambivalence in Indonesia" China Relations", Harvard Asia Quarterly 13(1): 24-31.

Merdeka (2017), "Profil the Jakarta Post," August 16, available at: https://profil.merdeka.com/indonesia/t/the-jakarta-post/ (accessed 16.08 .2017).

Nabbs-Keller, Greta (2011), "Growing Convergence, Greater Consequence: The Strategic Implications of Closer Indonesia-China Relations", Security Challenges 7(3): 23-41.

Oates, Sarah (2006), Television, Democracy and Elections in Russia, London: Routledge

Oxford Project Southeast Asia (2015), "Southeast Asia and Oxford", February 2, available at: http://projectsoutheastasia.com/about/southeast-asiaand-the-university-of-oxford (accessed 04.08.2016).

Pitlo (2013), "Fishing Wars: Competition for South China Sea's Fishery Resources," July 10, available at http://isnblog.ethz.ch/security/fishingwars-competition-for-south-china-seas-fishery-resources (accessed 24.10. 2015).

Pusat Data dan Informasi Badan Koordinasi Penanaman Modal Republik Jakarta (2017), “Kompilasi Data Investasi Jepang dan Tiongkok tahun 2007-2010," June 5.

Rama, Ali (2010), "China Emergence and Its Impact on ASEAN", Jakarta Post, February 4.

Roberts, Christopher B. and Erlina Widyaningsih (2015), "Indonesian Leadership in ASEAN: Mediation Agency and Extra-Regional Diplomacy", 
264-286, in Christopher B. Roberts, Ahmad D. Habir and Leonard C. Sebastian (eds.), Indonesia's Ascent: Power, Leadership and the Regional Order, London: Palgrave MacMillan.

Roy, Denny (2005), "Southeast Asia and China: Balancing or Bandwagoning?" Contemporary Southeast Asia 27(2): 305-322.

Simarmata, Salvatore (2014), Media dan Politik: Sikap Pers terhadap Pemerintahan Koalisi di Indonesia, Jakarta: Yayasan Pustaka Obor Indonesia.

Shambaugh, David (2005), "China Engages Asia: Reshaping the Regional Order", International Security 29(3): 64-99.

- - (2016), China's Future, New York: John Wiley \& Sons.

Smith, Steve, Amelia Hadfield and Tim Dunne (eds.) (2012), Foreign Policy: Theories, Actors, Cases, Oxford: Oxford University Press.

Straits Times (2018) “Inside China's US\$1 Billion Port in Sri Lanka where Ships Don't Want to Stop", April 18, available at: https://www.straitstimes.com/ asia/south-asia/inside-chinas-us1-billion-port-in-sri-lanka-where-ships-do nt-want-to-stop (accessed 08.07.2018).

Sukma, Rizal (2012), "Indonesia and the Emerging Sino-US Rivalry in Southeast Asia", available at: http://www.Ise.ac.uk/IDEAS/publications/reports/pdf/ SR015/SR015-SEAsia-Sukma-.pdf (accessed 13.08. 2017).

Supriyanto, Ristian Atriandi (2014), "Exercise Komodo and the South China Sea", Jakarta Post, March 29.

Suropati, Untung, Yohanes Sulaiman and Ian Montratama (2016), Arungi Samudra Bersama Sang Naga: Sinergi Poros Maritim Dunia dan Jalur Sutra Maritim Abad ke-21, Jakarta: Kompas Gramedia.

Suryadinata, Leo (1990), "Indonesia-China Relations: A Recent Breakthrough", Asian Survey 30(7): 682-696.

Tentara Nasional Indonesia Angkatan Laut (2015), "Masukan ARMABAR Kepada Pemerintah dalam Menyikapi Perkembangan Situasi di Laut Cina Selatan", May 5., Jakarta: Kementerian Politik Hukum dan Keamanan Republik Indonesia.

Tomotaka, Shoji (2008), “ASEAN Security Community: An Initiative for Peace and Stability", available at: http://www.nids.mod.go.jp/english/publication /kiyo/pdf/2008/bulletin_e2008_3.pdf (accessed 01.08.2017). 
U.S. Department of Defense (DoD) (2005), Annual Report to Congress: The Military Power of the People's Republic of China, available at: www.defense.gov/news/Jul2005/d20050719China.pdf

(accessed:

17.11.20

10).

U.S. DoD (2006), Annual Report to Congress Military Power of the People's Republic of China, available at: www.defense.gov/pubs/pdfs/China\%20Re port\%202006.pdf (accessed 17.11.2010).

- - (2007), Annual Report to Congress: Military Power of the People's Republic of China, available at: http://www.defense.gov/pubs/pdfs/070523-china-military-powerfinal.pdf (accessed 17.11.2010).

United States Department of the Homeland Security (2005), "The National Strategy for Maritime Security", September 20, available at: http://georgewbush-whitehouse.archives.gov/homeland/maritime-securi ty.html (accessed 13.03.2011).

U.S. Energy Information Administration (2012), "World Oil Transit Chokepoints: Malacca," August 22, available at: http://www.eia.doe.gov/cabs/world_oil _transit_chokepoints/malacca.html (accessed 31.05.2013).

Vaughn, Bruce (2011), "Indonesia: Domestic Politics, Strategic Dynamics, and US Interests," January 31, CRS Report for Congress, RL32394 (Congressional Research Service, The Library of Congress), 1-2.

Williams, Michael (1991), "China and Indonesia Make Up: Reflections on a Troubled Relationship", Indonesia: 145-158.

Wu, Chongbo (2011), "Forging Closer Sino-Indonesia Economic Relations and Policy Suggestions", Ritsumeikan International Affairs (10): 119-142.

Witular, Rendi A. (2014), "Jokowi Asks More of China," Jakarta Post, November 10.

Senia Febrica is a Researcher in the American Studies Center at the University of Indonesia and Director of the Maritime Affairs Programme at the Indonesian Institute of Advanced International Studies. 
32 | Senia Febrica and Suzie Sudarman

Suzie Sudarman is Director of the American Studies Center at the University of Indonesia. 
33 Senia Febrica and Suzie Sudarman 